\title{
Globalization and Pandemics: Interrogating the Differential Impact of Pandemics on States
}

\author{
Ochi Ijeoma Brigid \\ Department of Political Science, Nnamdi Azikiwe University, Awka, Anambra State, Nigeria
}

\begin{abstract}
The revolutionary interconnectedness of the planet through production flows, trade, technologies and finance representing increased globalization has eased the spread of pandemics. This has integrated the world into a single epidemiological system and resulted in calls for co-operation amongst countries. Despite this, countries' responses to the outbreak of pandemics have been largely characterized by panic and co-operation has been sacrificed on the altar of national interest. Pandemics have therefore affected different countries differently. This informs this paper's task to assess the underlying cause of the differential impacts of pandemics and to proffer plausible solution on how countries, especially the less developed ones can best adapt to the pressures emerging from pandemics in a globalized world. The paper was qualitative and time-series data relating to influenza pandemics, HIV/AIDS pandemic and the Coronavirus pandemic were extracted from secondary sources. Ogban-Iyam's theory of Social Production and Reproduction was adopted as a theoretical framework for analysis. The study revealed that the emergence of globalization and the resultant ease in the spread of pandemic is a consequence of the social relations that occur in the capitalist production system. It was found that the differences in the impact of pandemics result mainly from the capabilities of states and the degree of sophistication of their productive forces. It was therefore recommended that the best option to ease the adaptation of states to changes posed by pandemics in a globalized world is the development of their productive forces.
\end{abstract}

Keywords: Globalization, Pandemics, COVID-19, Influenza, HIV/AIDS

ORCID ID: 0000-0002-0473-8825

DOI: $10.7176 / \mathrm{IAGS} / 87-04$

Publication date:October $31^{\text {st }} 2020$

\section{Introduction}

The contemporary world is characterized by unprecedented levels of interaction between countries and thinning national borders such that exchange occurs between individuals across national boundaries on a daily basis. Extant literature has therefore dwelt extensively on the benefits and downsides of this global exchange. While some scholars, especially those of the right wing, emphasize the strong points of the globalization process and the benefits countries derive from them, left wing scholars have continually stressed that globalization has done more harm than good to the modern world. The task of this paper is not to take sides in this debate as globalization has shown itself to have far reaching positive and negative effects. It however seeks to contribute to the literature by examining the interface between globalization, the spread of pandemics and differences in the impact of pandemics in countries. This is necessitated by present realities occasioned by the increasing ease at which infectious diseases and pandemics spread across the world.

Available evidence shows that human populations have always been susceptible to pandemics and infectious diseases. Hence, in $165 \mathrm{AD}$, there was the Antonine plague which ravaged Asian Minor, Egypt, Greece and Italy, killing over a million people and decimating the Roman Empire. Since then, a number of similar, and perhaps more deadly, pandemics have followed. Examples include amongst others, Plague of Justinine, the Black Death, a number of flu pandemics, Cholera pandemics, the HIV pandemic and the Coronavirus pandemic (Knobler et al., 2006; Roos, 2020; WHO, 2005). It is important to note that many of these pandemics occurred in the $20^{\text {th }}$ and $21^{\text {st }}$ Century such that countless lives have been lost within the past 100 years. The past 50 years have been particularly distressing as the potential for diseases to travel from one settlement, city, country or region to others has increasingly been recognized. Consequently, the World Health Organization and the United Nations collaborated in initiating a special programme for Research and training in Infectious Diseases which provided a 67 page review linkage between globalization to the spread of infectious diseases in 2004.

The review pointed out that people and states show different levels of vulnerability to infectious diseases. It also noted that there are inequalities in capacity and access to disease surveillance and monitoring systems (Saker et al., 2018). The solution was situated amongst others, in the enhancement of the global dimension of infectious diseases. Calls therefore have been made for increased co-operation in combating pandemics and other infectious diseases. While acceding that more co-operation would lead to a reduction in the vulnerability of states to infectious diseases, this paper notes that the differences in vulnerability and capacity to access global surveillance and disease monitoring systems do not emanate solely from lack of co-operation amongst states. In fact, globalization has brought with it so much co-operation that a problem in one part of the world easily gains global attention. Pandemics spanning across countries and continents have always created incentives for global co- 
operation that international organizations and countries commit funds and render assistance to affected countries/regions. International organizations which have contributed in this regard include: the World Health Organization, the European Center for Disease Control, Global Alliance for Vaccines and Immunization, amongst others (Knobler et al., 2006). Consequently, states' capacity is implicated as an impediment to their ability to access and utilize disease surveillance and monitoring systems and reduce their vulnerability. This paper seeks to interrogate the interface between the state, global linkages and the spread/containment of pandemics. It attempts to answer the following questions: How does state capacity account for the differential impact of globalization on pandemics across countries? How can states, especially developing ones, best adapt to the changes posed by pandemics in a globalized world?

\section{Conceptual Clarification}

Here, the conceptual issues relating to the major concepts that reoccur in the paper are examined and the concepts are operationally defined so as to ease readability and comprehension of the study. Concepts used here include; globalization and pandemics.

\section{Globalization}

The concept of globalization like other social science concepts lacks a universally acceptable definition as scholars tend to use in within specific contexts. Consequently, it has been referred to as: the intensification of economic, political and socio-cultural activities across international boundaries (Akindele, 1990 cited in Ibrahim, 2018); the transfer, exchange and movement of ideas, technologies, information, cultures, practices that affect the political, economic, socio-cultural aspect of societies across international boundaries to receive global or universal recognition (Ibrahim, 2018). It is perceived as a process of integrating different parts of the world into a global economy via the internationalization of capitalism. This perception underpins the difference between globalization, globalism and de-globalization. Globalization here is seen as the process that brings about increased globalism. Globalism on its part is a state of the world involving networks of interdependence at multi-continental distances (Wells, 2001). The presence and increase in these networks is called globalization. Globalization creates points of connection and a resulting fuller integration. In contrast, de-globalization refers to a process that brings about reduced globalism. De-globalization results in a decrease in points of connection and reduced integration of the world. These networks and points of connection emerge through flows and influences of capital and goods, information and ideas, people as well as environmentally and biologically relevant substances (like vectors and pathogens) (Wells, 2001). A common thread in definitions of globalization is that it connotes an emergence of interconnected world characterized by open free-market economies (Angalapu \& Ikporukpo, 2020). This is such that the world is increasingly perceived as a 'global village' wherein an event that occurs in one part has rippling effects on other parts. The literature on globalization is characterized by conceptual debates bordering on the drivers and consequences of globalization.

The dominant view held by many rightist/neoliberal scholars attributes globalization to the post World War II technological innovations which has increased the ease of movement and exchange of information across different parts of the globe (Williamson, 1998). The period after the Second World War was a time of remarkable technological progress. During this period, man gained such mastery of himself and his environment so much that things which would hitherto be dismissed as science fiction came to be accepted as a part of everyday life. There were such massive technological innovations in transportation and communication that information could be dispatched within seconds through mobile communication devices and the internet to different parts of the world at minimal cost. There are also fast transportation systems which use magnetic levitations to convey commuters at a speed of over 200 miles per hour (Sachs, 2015). All these connect different parts of the world and integrate them into one big global village. Another view is that which ties globalization to the export of capitalism by the western capitalist powers of Europe and the United States of America to other parts of the world. While this view is not entirely different from the previous one, it emphasizes the adverse consequences of globalization on countries, especially developing ones.

\section{Pandemics}

The World Health Organization defines a pandemic as a worldwide spread of a new disease (WHO, 2010). This definition gives an impression that a pandemic is a disease that has spread to all parts of the world. This is only marginally true as a disease only needs to spread to a large part of the world to be declared a pandemic. A broader definition sees a pandemic as a very contagious disease resulting from a new pathogenic strain that has spread across an entire country or other large landmass spanning continents or the entire world (Kurt, 2020). A related concept is epidemic. An epidemic is a contagious disease that affects numerous people at a time in a locality where the disease is not permanently prevalent. It is "an increase, often sudden, in the number of cases of a disease above what is normally expected in a population of an area" (Center for Disease Control, 2012). The difference between pandemic and epidemic is the geographical landmass it covers. While an epidemic occurs at the level of a region or community, pandemics occur at the national, international and intercontinental levels. To put it more clearly, a pandemic is an epidemic that has spread over several countries or continents, usually affecting a large number of 
people. Some key features of pandemics include: wide geographical extension, disease movement, novelty, severity, high attack rates and explosiveness, minimal population immunity, infectiousness and contagious status (Qiu et al., 2017).

\section{Methodology}

This study is a qualitative research that utilized longitudinal research design. Specifically, the time series research design was utilized to study the interface between globalization and the emergence as well as spread of pandemics in the world. This design is considered appropriate because pandemics and its effects are not new to the world. Consequently, it would be hasty to draw a conclusion on the effects of globalization on the spread of pandemics with just one outbreak. This therefore necessitates the adoption of a historical design such as the time series in order to establish a trend in the analysis of the variables in this study. Data was gathered from secondary sources, specifically, journal articles, books, television interviews, and personal reflections as a participant observer of the covid-19 pandemic. Descriptive method was used in the presentation of data and analysis was done using content analysis.

\section{Literature Review}

There is a flourishing literature on the nexus between globalization and the spread of pandemics. A bulk of the literature establishes a synergy between the interconnectedness of countries - globalization - and the spread of infectious diseases (Saker et al., 2018). These literatures contend that globalization is driven by increased movement which serves as an incentive for pathogens to be carried across geo-political boundaries. Thus, Life threatening diseases are parts of globalization. In 2003, for example, a deadly disease form of pneumonia known as Severe Acute Respiratory Syndrome (SARS) originated in China and posed a worldwide health threat as airline passengers infected with the virus spread the illness.

Globalization therefore, comes with massive movement and exchange that eases the spread of pandemics across national, regional and continental borders. The globalization process is driven by two major factors, movement of people and massive exchange of information (Wells, 2001). There is such massive movement that people tour the world daily for business or leisure. In fact, international travel is one of the fastest growing industries all over the world (Sachs, 2015). "An estimated 700 million tourists cross international borders each year. About 60 million people from other countries travel annually to the United States; around the same number of U.S. citizens travel internationally and then return" (Knobler, Mehmoud, \& Lemoh, 2006, p. 24). When people who are infected by some pandemic causing pathogen move across national boundaries, these pathogens follow them, spread to new areas and infect new people. History has provided ample evidence to substantiate this point. The spread of such pandemics as the Antonine Plague, Plague of Justinine, Black Death, Influenza (Russian flu, Spanish flu, Asian flu and Hong Kong Flu), HIV, and the Coronavirus have all been tied to the movement of people (Gallagher, 2014; Atlas Magazine, 2020; MPHOnline, 2020; Jarus, 2020). Also, the recent rapid spread of the 2019-nCOV virus from China to other parts of the world is closely tied to globalization and the attendant movement of people across countries of the world (Jarus, 2020; Clydesdale, nd). In fact, a single infected person can spread a pandemic to all parts of the world by simply boarding a ship or a flight (Saker, Lee, Cannito, Gilmore, \& Campbell-Lendrum, 2004). This is why restriction of movement has been largely adopted in recent times as a control mechanism for such pandemics as Ebola and Coronavirus.

Closely associated with the spread by infected persons through movement is the inadvertent transfer of pathogens through food. "Consumer demand and expectations have increased and food production and processing activities have become more geographically fragmented (e.g., foods produced in one locale being processed elsewhere)" (Knobler et al., 2006, p. 27). The advent of modern fast transport system has made it easy for disease causing vectors to be transported from one part of the world to the other. It has for instance, been established that the mosquito vectors can hitch rides in the wheel wells of airplanes (Knobler et al., 2006). Also, the worldwide movement of people across the globe has occasioned a global trade in food and animals as consumer demands have gained an unprecedented level of universality. The flow of food across national boundaries however, raises serious concerns about the global spread of antibiotic resistance associated with the consumption of animals fed with antibiotic food (Knobler et al., 2006). This is very distressing as most pandemics emerge from zoonotic diseases.

The ready availability of information in a globalized world increases the incentive for people to move. As information about living conditions becomes readily available to people in all parts of the world, people living under deplorable living conditions strive to change their circumstances by relocating to places with better living standards (Knobler et al., 2006).Writing on this situation in Africa, Sachs (2015, p. 342) asserted that, "in West Africa there was drought and food crisis in the Sahel, covering Mali, Chad, and Niger; in East Africa, there was drought and food crisis in the Horn of Africa, covering Ethiopia, Somalia, Northern Uganda, Northeast Kenya, and Djibouti. In both cases, the drought and resulting famines led to large population movements and resurgent violence as migrants clashed with local populations." This explains the upsurge in the rate of legal and illegal 
migration of people from poor countries to relatively advanced countries of Europe. The number of international migrants globally reached 272 million people in 2019 reflecting an increase of 51 million since 2010 (IOM, 2019). This figure constitutes 3.5 percent of the world population compared to 2.8 percent in the year 2000 (IOM, 2019). Migration has been essentially fueled by a cluster of factors including hardships, instability and conflict (Sachs, 2015). Similarly, the availability of resources (human and material) propels people and industries in the developed world to move even to the most underdeveloped parts of the world in search of those resources (Jones, 2012). This explains the presence of multinational companies in the telecommunication, resource extraction and construction industries in almost all parts of the world. There is therefore, an exchange, not only of culture, food and clothing but also of diseases. As such, it is difficult to isolate an infectious disease in a single geo-political territory.

Another factor emerging from the global exchange that can contribute to the spread of pandemics is an upsurge in the number of displaced people. In recent years, the world has recorded countless incidences of conflicts across regions of the world. There have been conflicts in the Middle East with such countries as Syria, Iran, amongst others as major actors. Similarly, the African continent has seen some major incidence of conflicts in such places as Dafur, Congo, Mali, amongst others (Homer-Dixon, 2000). These conflicts result in both internal and external displacement of people which in turn creates incentive for migration. As displaced people move across national and international boundaries, they become open to new strains of infectious diseases borne by pathogens and vectors. More so, their movement creates a path for pandemics to tour the globe. The movement of people also results in stress on local medical facilities as it becomes difficult to monitor and provide care to the growing number of static and mobile population.

Another crucial factor resulting from globalization and serving as an incentive for pandemics to thrive is the fragmentation of the production process. Due to increased integration in the world, it is now possible to gather raw materials from one part of the world, produce in another, package in another and distribute to yet, another part of the world. For many sophisticated products, parts are produced in different countries and assembled in another. Typical examples of this are: telecommunication devices, automobiles and some medical facilities. In making these products, pathogens, especially those transmissible on surfaces, are likely to be transferred between handlers of these products. This is made even easier when the duration of potency of these pathogens are higher than the time it takes to transport them across regions.

Addressed in the literature also, is the impact of globalization on the control of pandemics. Many authors contend that globalization has made it easier for states to control and contain pandemics (Giovanni et al., 2008). Yet, others opt for an opposite view, contending that while globalization eases the spread of pandemics, it throws up imbalances when it comes to the control of pandemics (Ruiz Estrada \& Khan, 2020). The dominant trend in the literature is the contention that the presence of numerous points of connection in the world provides an avenue for co-operation in combating disease outbreak in general and pandemics in particular. This has informed calls for global alliances in research, surveillance and funding for pandemic control (Saker et al., 2018).

From the previous paragraphs, it is clear that globalization throws up a cluster of factors that eases the spread of pandemics. Amongst the most prominent of these factors are: Information flows, tourism, food and animal consumption pattern, migration, conflicts and resultant displacement of people. All these factors have the potential of throwing up severe adverse and potentially devastating consequences for global and regional health. In sum, globalization is driven by movement which eases the spread of pandemics. An analysis of the spread pattern of some pandemics in history gives credence to this fact.

A factor largely ignored however in the literature on globalization and pandemic is the role of the state as an intervening variable in the interface between globalization and the spread, surveillance, control and containment of pandemics. Herein lays the gap which this paper seeks to fill.

\section{Theoretical Framework}

This study employs Ogban-Iyam's theory of Social Production and Reproduction as a theoretical framework for analysis of the interface between globalization and pandemics. Premised on the thesis that survival and security are the primary goals of every living thing, the theory holds that for humans to survive and be secure, they must produce and reproduce their means of sustenance and their kind (Ogban-Iyam, 2005; 2018). As with the Marxian tradition, the theory takes it for granted that production and reproduction of human needs is essentially social and not personal. Hence, at a rudimentary level, individuals in the family interact to produce their needs. Going further, families interact with other families within a community, communities interact with other communities within a state, and states interact with other states in the international system. The theory of social production and reproduction identifies three core elements employed in the production of human needs: quality of labour, nonhuman physical resources for production and interpersonal relations. The quality of labour entails physical strength, knowledge and skills; non-human physical resources includes tools and objects for applying the tools; and interpersonal relations embodying the relationship between the person who decides on what is to be produced, exchanged, distributed and consumed and the person who produces, exchanges, distributes and consumes.

The major idea and core components of this theory generates a perfect picture for an analysis of the nexus 
between globalization and the spread as well as differential impact of pandemics on countries of the world. Drawing from the theory, globalization can be seen to be a product of the interaction between people in an effort to produce and reproduce their needs. It is easy to understand from this theory that as production occurs and becomes increasingly sophisticated, there would be an accompanying increase in the rate of interaction between people. This point is clear when one considers the fact that production at a very rudimentary level, for subsistence, involves fewer people than commercial production, for export which could occur between a very large numbers of people across geo-political boundaries. More so, the scale of production is a product of the quality of labour, the quality of non-human resources and the social relations of production adopted within that production process. A highly specialized labour power applied to technological production tools and enhanced objects of nature would inevitably require a broader scope of interaction between people and even a hierarchical/class line of interaction as is found in the modern world.

Production in the modern world has become very sophisticated so much that items utilized for production are gotten from one part of the world, production is done in another, products are packaged in another and distribution are made to other parts. This is possible through interaction between different individuals with specialized labour and even firms operating across national boundaries. The contemporary world system is therefore an interwoven network of exchange. In man's effort to better produce his needs, there is essentially an exchange of almost everything - products, finance, information, knowledge, skills, machinery to produce man's needs. This global exchange has resulted in a world so closely knit together that a phenomenon or event in one part of the world easily ripples and spreads into other parts.

In production, humans tend to consciously produce things that would improve their survival, however, the production process, the tools utilized and the process of distribution could throw up unintended consequences. For instance, in an effort to produce man's needs, there is a high dependent on fossil fuel to power industries. This dependency throws up different forms of environmental pollution that leads to the emergence and increased spread of diseases (Tuttle \& Breit, 1999). Consequently, the emergence and spread of many diseases is deeply rooted in the production process. If it does not emerge or spread as a result of the production process, the capacity of man to curtail it would depend on the degree of sophistication of the production process. More so, as social interactions occur in the production process and people move from place to place to produce their needs, there is a tendency for them to transport pathogens and new, highly contagious and severe pathogens are transported through this means, pandemic outbreaks become inevitable.

In consonance with this theory, the spread of pandemics in the world is hinged on globalization which is driven by the sophistication of the production process. It is important to state therefore that whether positive or negative, the impact of globalization is felt on a country depending on the sophistication of the production process. Pandemics are negative impacts of globalization, hence, their effects on a particular state is determined by the degree of sophistication of the production process of such state. Pandemics like other diseases have differential effects on societies due to the differences in societies' capacity to produce and reproduce the tools needed to adapt and mitigate its effects. Drawing from this logic, it is hypothesized that: the differences in the impact of pandemics emerge from differences in the productive capacity of states, and adapting to novel challenges posed by pandemics in a globalized world would require an increase in the sophistication of the production process that deals with the specific pandemic.

\section{The Spread of Some Pandemics}

Infectious diseases spread through three major means, from person to person, through the air and through contact with infected objects, animals or surfaces. All pandemics in history have shown the potential of been very infectious and contagious. There have been several pandemics in the world amongst which are: Plague of Justinine, the Black Death, influenza pandemics, cholera pandemics, the HIV and AIDS pandemic and the Coronavirus pandemic (Atlas Magazine, 2020; Jarus, 2020; Qiu, Rutherford, Mao, \& Chu, 2017). The spread pattern of some of these pandemics is briefly discussed below:

The Coronavirus Pandemic:

Coronavirus is a family of viruses that cause respiratory diseases. The $21^{\text {st }}$ Century has witnessed three major coronavirus outbreaks - SARS-Cov, MERS-Cov and nCov-19. SARS (Severe Acute Respiratory Syndrome), first identified in November 2002 in the Guangdong province of Southern China is a viral respiratory illness caused by coronavirus that spread to 26 countries in North America, Europe, South America and Asia before it was finally contained in 2003 (Wu \& Chow, 2020). There were 8,098 recorded cases and 774 deaths resulting from the outbreak. MERS (Middle East respiratory syndrome), first reported in Saudi Arabia in 2012, affected 27 countries in Africa, Asia, Europe and North America. Since its outbreak in 2012, a total of 2,494 cases and death toll of 858 people have been attributed to the Middle East Respiratory Syndrome (Wu \& Chow, 2020).

The outbreak of the novel coronavirus pandemic was first recorded in 2019 at Wuhan, China. It has now spread to 190 countries across all continents of the world. A coronavirus outbreak that emerged in China in December, and is now spreading into other countries, has sickened more than 430,000 people and killed more than 
19,000. Public health officials are racing to contain the pathogen, but this is not the first time the world has had to battle the spread of a novel coronavirus (Wu \& Chow, 2020). It is noteworthy to point out that the ncov-19 virus and other previous strains of the corona virus are zoonotic. They were transmitted from animals to humans. More so, their spread has been eased by increased globalization so much that the new strain has reached almost every country of the world. A comparison of the three corona virus strains reveals that novel corona virus has been more devastating than all other previous strains, having a wider country reach and more casualties than all previous strains combined.

Table 1: Comparison of Coronavirus Pandemics

\begin{tabular}{clclcc} 
Year & Pathogen & No. of Cases & Deaths & Mortality Rate & $\begin{array}{c}\text { Number } \\
\text { Affected }\end{array}$ \\
\hline 2019 & & $\begin{array}{l}741,030 \\
\text { (Increasing) }\end{array}$ & $\begin{array}{l}35,114 \\
\text { (Increasing) }\end{array}$ & $\begin{array}{l}3.6 \% \\
\text { (increasing) }\end{array}$ & \\
& nCov-19 & & & 27 \\
2012 & MERS- & 2,499 & 861 & $34.45 \%$ & 27 \\
& Cov & 8,437 & 813 & $9.63 \%$ & 26 \\
\end{tabular}

Source: Adapted from: Wu and Chow (2020)

\section{The HIV and AIDS Pandemic}

AIDS is the acronym for Acquired Immunodeficiency Syndrome. It is a medical condition caused by weakness in the immune system and attendant susceptibility to diseases. The syndrome is caused by the HIV (Human Immunodeficiency Virus) virus which weakens its victims' immune systems. It was officially discovered in the United States in the early 1980s but scientific evidence links its origin to the 1920s in the Democratic Republic of Congo. The virus was acquired by hunters through contact with some species of primates in Sub-Saharan Africa including, Chimpanzees, African Green Monkeys and Mandrills (Hahn \& Sharp, 2011). The virus is said to have spread from Kinshasa through other parts of Congo to other areas in Sub-Saharan Africa by being transported by movements along the historic trade routes of the Congo basin. By the 1960s, the virus had made its way to Haiti when many Haitians who were working in DRC returned to Haiti.

The virus presence was felt in the United States by the early 1980s when people began to fall sick. Four main at-risk groups were identified - homosexuals, hemophiliacs, heroin addicts and Haitians. Recent data shows that 36.8 million people currently live with HIV/AIDS (Avert, 2020). The WHO African region remains most severely affected, with nearly 1 in every 25 adults (3.9\%) living with HIV and accounting for more than two-thirds of the people living with HIV worldwide (World Health Organization, 2018). Worth noting is the fact that HIV like other pandemics is driven by movement. It does not move on its own but humans and their activities propel its spread from country to country.

Influenza Pandemic:

An influenza pandemic outbreak occurs when an animal influenza virus acquires the capacity to infect and sustain human to human transmissions. The outbreak of influenza pandemics are often referred to as flu outbreaks. Five major flu outbreaks have been recorded between 1889 to date. First, was the 1889 Russian flu, then there was the 1918 Spanish Flu which was followed by the 1957 Asian Flu and finally the 2009 H1N1 flu pandemic (Little, 2020b). Of these pandemics, the Spanish flu of 1918 provides a perfect case study of how the flu pandemic spread. The Spanish flu emerged in Europe at the height of the First World War when European countries were at gore with each other. Due to the war, the media in numerous countries were censored and evidence of flu outbreak concealed. When a prominent figure like President Wilson caught it, it was presented in the media as a case of severe cold. The war and resulting cover-up eased the spread of the pandemic across Europe. The 1918 influenza pandemic was estimated to have had a case-fatality ratio of less than $5 \%$ but had an enormous impact due to widespread transmission. By the end of 1919, it had infected up to a third of the world's population and killed some 50 million people (Little, 2020a).

While the media censorship played a crucial role in the spread of the pandemic, it is crucial to note the role played by the war and colonialism in the spread of the 1918 influenza flu across Europe and other parts of the world. The pandemic circulated at a period when WWI was at its peak and countries were combating with each other. It was therefore easy for soldiers to pick up the flu from foreign territories and spread it to their home country. Similarly, the period of this pandemic was during the colonial era when European countries had territories all over the world. It was therefore easy for the pandemic to reach these territories which were occupied by European powers. Also evident here is the role of transnational movement in the spread of pandemics.

From the above, it can be seen that right from early times, movement has been the driver of the spread of pandemics. Consequently, it is easy to see why globalization is implicated in the spread of pandemics as movement has not just become increasingly easy but less hectic and fast. Nevertheless, pandemics do not exist in a vacuum. Most of the diseases and viruses now named pandemic are offshoots of pathogens and infectious diseases. As such, 
an infectious epidemic in the present era can become a pandemic in the future. This is quite frightening as there are countless pathogens in the world with potentially devastating capabilities which can be fuelled by globalization to become a pandemic. The table below contains a few examples of such pathogens and infectious diseases.

Table 2: Pathogens and Infectious Diseases

\begin{tabular}{|c|c|c|c|c|c|c|}
\hline $\begin{array}{l}\text { Name of the } \\
\text { virus }\end{array}$ & Nature of the virus & Year & $\begin{array}{l}\text { Number } \\
\text { of } \\
\text { people } \\
\text { affected }\end{array}$ & $\begin{array}{l}\text { Number } \\
\text { of } \\
\text { deaths }\end{array}$ & $\begin{array}{l}\text { Mortality } \\
\text { rate }\end{array}$ & $\begin{array}{c}\text { Number } \\
\text { of } \\
\text { affected } \\
\text { countries } \\
\text { or } \\
\text { territories }\end{array}$ \\
\hline 2019-nCoV & $\begin{array}{l}\text { Coronavirus is a new form of } \\
\text { respiratory syndrome. The virus, } \\
\text { which first appeared in China, is of } \\
\text { animal origin and is transmissible } \\
\text { between humans }\end{array}$ & 2019 & $\begin{array}{c}9072 \\
642\end{array}$ & 471176 & $5.19 \%$ & 210 \\
\hline $\begin{array}{l}\text { Avian } \\
\text { influenza A } \\
\text { H7N9 }\end{array}$ & $\begin{array}{l}\text { Avian influenza virus. It was first } \\
\text { discovered in Shanghai. The virus } \\
\text { normally affects birds. }\end{array}$ & 2013 & 1568 & 616 & $39.30 \%$ & 3 \\
\hline MERS & $\begin{array}{l}\text { Middle East Respiratory Syndrome } \\
\text { (MERS) viral respiratory disease } \\
\text { first detected in Saudi Arabia. }\end{array}$ & 2012 & 2494 & 858 & $34.40 \%$ & 28 \\
\hline H1N1 & $\begin{array}{l}\text { Swine influenza: severe respiratory } \\
\text { disease coming from different } \\
\text { swine, avian and human influenza } \\
\text { viruses. }\end{array}$ & 2009 & $\begin{array}{c}>762 \\
630000\end{array}$ & $\begin{array}{c}>284 \\
500\end{array}$ & $0.02 \%$ & 214 \\
\hline SARS & $\begin{array}{l}\text { Acute and severe respiratory } \\
\text { syndrome. The epidemic, } \\
\text { originating from China, is believed } \\
\text { to stem from bats. }\end{array}$ & 2002 & 8096 & 774 & $9.60 \%$ & 29 \\
\hline Nipah & $\begin{array}{l}\text { Viral infection which appeared in } \\
\text { Malaysia and Singapore. It is } \\
\text { transmissible to human beings via } \\
\text { contaminated pork. The natural } \\
\text { hosts of this virus are bats. }\end{array}$ & 1998 & 513 & 398 & $77.60 \%$ & 2 \\
\hline H5N1 & $\begin{array}{l}\text { Avian influenza virus. The first } \\
\text { human case of infection was in Hong } \\
\text { Kong. }\end{array}$ & 1997 & 861 & 455 & $52.80 \%$ & 18 \\
\hline Henipavirus & $\begin{array}{l}\text { A deadly respiratory or neurological } \\
\text { impairment. It is transmissible to } \\
\text { horses and human beings through } \\
\text { bats. }\end{array}$ & 1994 & 7 & 4 & $57 \%$ & 1 \\
\hline Ebola & $\begin{array}{l}\text { A hemorrhagic fever which } \\
\text { originates from bats. The outbreak } \\
\text { of the virus is Africa. }\end{array}$ & 1976 & 33577 & 13562 & $40.40 \%$ & 9 \\
\hline Marburg & $\begin{array}{l}\text { Endemic virus which has spread in } \\
\text { several African countries. }\end{array}$ & 1967 & 466 & 373 & $80 \%$ & 11 \\
\hline
\end{tabular}

Source: (Atlas Magazine, 2020)

The table above contains a broad spectrum of pathogens that has infected people across national boundaries from 1967 till date. These viruses are all infectious and it only requires the emergence of a new, highly contagious and unfamiliar strain for a new pandemic to threaten the world. This is even more worrisome with the increased ease of movement resulting from the globalization process that serves as a vehicle to convey these pandemics throughout the globe. This explains why a restriction on movement has been often adopted as a strategy to contain the spread of pandemics over the years. There has been travel bans, stringent anti-immigration policies and even embargoes on goods from certain countries. While there is a call for co-operation amongst countries, the realities posed by pandemics often make countries more individualistic in their approaches than co-operative as each tries to contain the pandemic and sustain its economy. There have therefore been differential impacts of pandemics on countries around the world. 


\section{The Differential Impact of Pandemics on States}

The increasing interconnectedness of the planet through trade, finance, technologies, production flows, migration, and social networks has brought revolutionary progress and problems to states in the contemporary world. The world has come to be largely interconnected and there has been major ease of movement and exchange of information between different parts of the world. A century and a half ago, it took about 365 days to circumnavigate the globe by ship; today it takes less than 36 hours (Knobler et al., 2006). More so, the advent of modern information and communication technology has made it possible for information to be transmitted from one end of the globe to the other within minutes at minimal cost. With this interconnectedness is a world population of 7.2 billion people looking for economic improvement. There has been significant improvement in places like China, Hong Kong, Taiwan, Singapore, amongst others. China for instance has had such remarkable improvement that they have been generating an average GDP per capita of $10 \%$ since 1978 following the adoption of market reforms by the Deng Xiaoping administration (Sachs, 2015). It is however, not all rosy as development have not been even in all areas of the world and not all countries of the world has harnessed the potentials of globalization for development in same capacity. The improvement in the economy of some countries has been accompanied by continuing poverty and widening inequality in others.

Many parts of the world has experienced progress, enjoyed longevity and better health outcomes than previous generations, yet at least one (1) billion people continue to live in poverty that they struggle for the bare minimum required for daily survival. "The poorest of the poor face the daily life and death challenges of insufficient nutrition, lack of health care, unsafe shelter, and the lack of safe drinking water and sanitation" (Sachs, 2015 , p. 23). In fact, the world has been largely polarized into two - developing and developed countries. While the developed world consist mainly of the industrialized capitalist powers of Europe and America, many countries in Asia, Latin America, Africa make up the developing world. This difference gives a picture of two different worlds, one being economically prosperous as a result of the application of advanced technologies to the production process while the other keeps struggling economically due to its reliance on primitive technology for production. This places a big question mark on the contention that: "as countries 'globalize' their citizens benefit, in the form of access to a wider variety of goods and services, lower prices, more and better-paying jobs, improved health, and higher overall living standards" (Giovanni et al., 2008, p. 8). In fact, Knobler et al (2006) noted very correctly that poor countries of the world are still poor, violence is increasing, and the same diseases still exist. An interesting paradox is that the benefits of an interconnected world are unevenly distributed while the risks, especially the health risks keep rising for all parts of the world.

Pandemics throughout history have had enormous adverse impacts on countries all over the world. They have a wide range of negative economic, social and political effects. The first and perhaps, obvious impact of pandemic is on the health of citizens. Pandemics have the potential to cause high morbidity and mortality in the world, and in fact they may account for a quarter to a third of global mortality (Verikios et al., 2015). Economically, pandemics result in direct and indirect economic costs on countries. The direct costs are enormous and they entail the direct expenditure made on rendering healthcare services to the sick, combating the spread as well as sourcing for a cure/vaccine for a pandemic. The Global Health Risk Framework for the Future estimates that the direct cost of infectious, including pandemics, every year averages 60 billion US dollars worldwide. Indirect costs are also massive. They include everything emanating from pandemics that contribute to a decline in the GDP (Qiu et al., 2017). The outbreak of a pandemic often comes with negative consequences on certain sectors of the economy which in turn reduce the GDP of countries affected. A novel example is the outbreak of the nCov-19 which has closed down markets, stifled international travels and tourism, and crippled government business all over the world. In April, the International Monetary Fund (IMF) predicted that global output would shrink by $3 \%$ in 2020 due to COVID-19 (Kurt, 2020).

Historical evidence also shows pandemics to have had massive adverse social impacts on countries. The 1918 influenza outbreak was named Spanish flu, signalling a stigmatizing effect. Also, Haitians, homosexuals and heroin users were identified as the main at risk group following the outbreak of the HIV/AIDS pandemic in the United States (World Health Organization, 2018; Gallagher, 2014). These groups were highly stigmatized against. The novel corona virus was called the 'Chinese Virus' by US president Donald Trump. Other social effects of pandemics include the closure of schools, restriction of public gatherings and stoppage or reduction of sporting events. The restriction of public gatherings and the closure of schools are mainly adopted by countries to control the spread of pandemics. The United States adopted it in combating the Spanish flu of 1918. Also, the Nigerian government and governments of other countries worldwide have adopted this measure to tackle the novel coronavirus 2019 pandemic. Thus, while social gatherings are often restricted to contain pandemic outbreaks, this act amounts to adverse social consequences that leave people indoors and turn lively neighbourhoods into quiet inactive places.

While pandemics clearly take its toll on all countries of the world, literary and empirical evidence have established that it affects the different parts of the world differently. The specific experiences from same pandemic vary from country to country (Saker et al., 2018). In fact, the severity of diseases, pandemics inclusive, across the 
globe vary depending on degree of sophistication of the production relating to disease control. All components of the productive forces are important in the management of pandemics. There is therefore, a need for sophisticated level of labour power (knowledge and skills needed to manage and control diseases), object of labour (the natural embodiment of that environment - weather, water quality and air quality) and the means of labour (healthcare facilities and equipments with which diseases are managed - ventilators, testing kits and other accessories). The capacity to produce these is not the same in all countries. Hence, while antiretroviral agents have been effectively adopted in the United States and other developed countries for the treatment of HIV and other infections, SubSaharan Africa and other resource constrained parts of the world continually face the problem of poor delivery of anti-retroviral agents (Knobler et al., 2006). This is because Africa lacks sophistication in terms of the production of anti-retroviral drugs and depends largely on the production and supply by the developed world. It is therefore not surprising that Sub-Saharan Africa remains worst affected by HIV/AIDS pandemic.

Table 3: HIV/AIDS Prevalence across continents

\begin{tabular}{ll} 
Region & Number Infected People \\
\hline East and Southern Africa & 19.6 million \\
Western and Central Africa & 6.1 million \\
Asia and Pacific & 5.2 million \\
West and Central Europe and North America & 2.2 million \\
Latin America & 1.8 million \\
East Europe and Central Asia & 1.4 million \\
Carribean & 310,000 \\
Middle East & 220,000 \\
North Africa & 530,000
\end{tabular}

\section{Source: (Avert, 2020)}

In addition to the imbalances in access to anti-retroviral treatment are imbalances in drug research and development efforts directed towards developed and developing countries. Within the last decade, pharmaceutical companies have produced more than 2000 new vaccines, yet, only six of these are for treatment of tropical diseases (Knobler et al., 2006). The reason for this is not far-fetched as most of these pharmaceutical companies are owned and managed by developed countries. The implication of this is that there are no vaccines for many tropical diseases and the eventual outbreak of a pandemic from such diseases would spell catastrophe for the world. Vaccines have more than earned their reputation as one of the greatest public health tools in history (Knobler et al., 2006). The invention of vaccines against such diseases as polio, small pox and measles has helped mankind tackle a bulk of his medical problems and live longer lives. However, their utility in many developing countries is limited by weak or nonexistent public health infrastructures and a lack of resources (Knobler et al., 2006). Peculiar institutional, political, environmental, cultural and other constrains continue to limit the capacity of many states, especially developing ones, to make optimal use of even the available vaccines. These factors also shape states' capacity to manage pandemic outbreaks. Peculiar experiences of some countries in dealing with the coronavirus pandemic provide a case in point.

China's capacity to adapt to the novel coronavirus increased around April 2020 and public places were reopened after months of closure. Around the same time, Europe and North America witnessed increased incident reports. As they began to ease, Latin America and Asia started experiencing an increase in cases. The period between April and July has seen Latin America rise to the epicentre of the pandemic. Brazil has recorded the highest number of casualties with over 2 million cases and a death toll of 76,688 (BBC News, 2020; European Center for Disease Prevention and Control, 2020). The Chinese as well as European countries and North American countries' ability to adapt quickly and contain the spread of the pandemic indicates the strong capacity of their productive system relating to healthcare. The healthcare facilities in the contemporary world are technology and knowledge driven. The degree of sophistication of a country's healthcare system is dependent on the quality of technology and knowledge applied. For instance, tackling covid-19 requires the use of ventilators, testing kits and well equipped isolation centers in addition to professional healthcare practitioners with requisite knowledge on disease control and use of healthcare technology. While the developed countries of Europe, North America and China are able to produce these, most developing countries in Africa and Latin America depend on other countries for these essential healthcare infrastructure. The comparative worldwide data on Covid 19 extracted from the European Centre for Disease Prevention and Control (ECDC) offers an interesting evidence for analysis. 


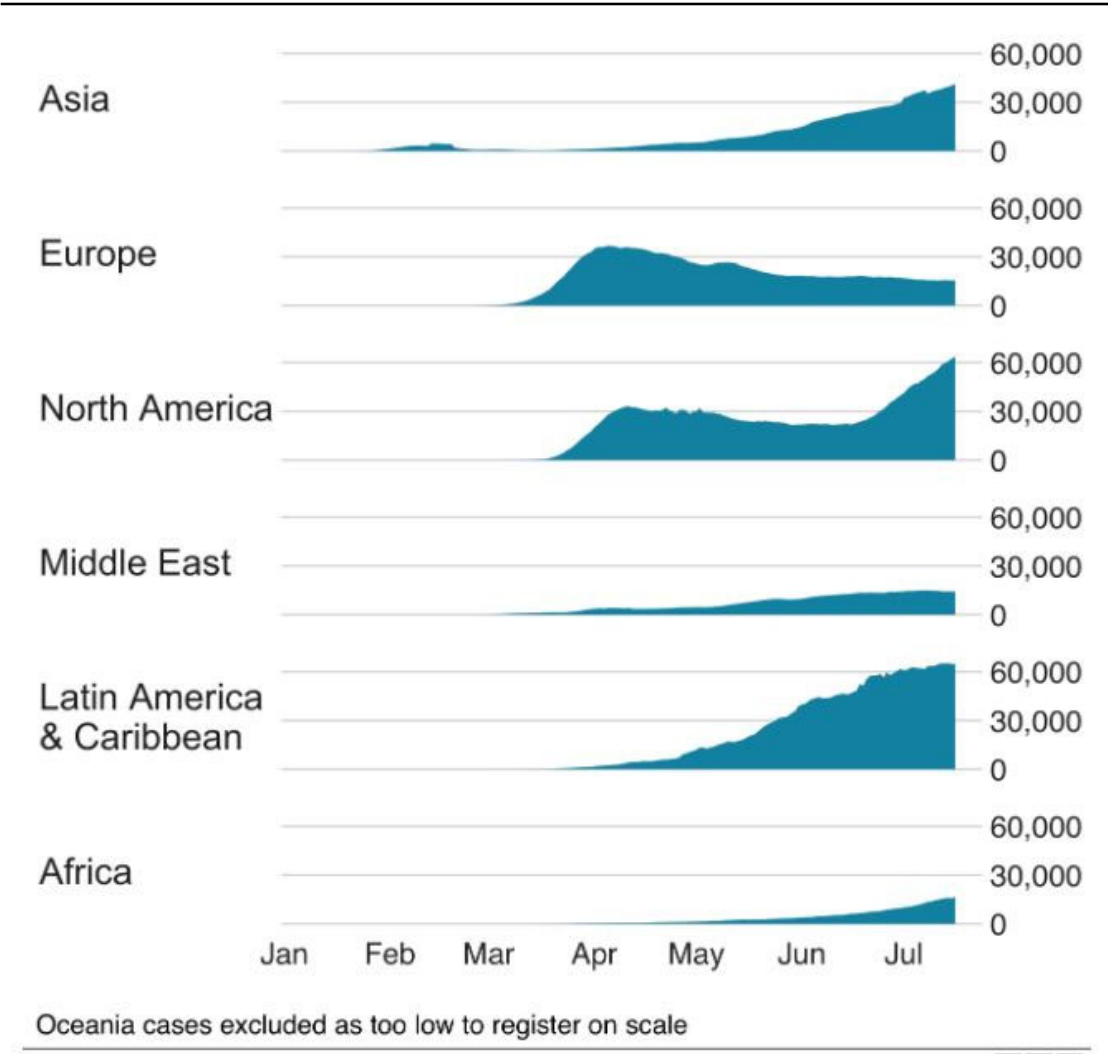

Figure 1: Covid 19 Cases compared by continent

Source: (European Center for Disease Prevention and Control, 2020; BBC News, 2020)

Data above shows differences in casualty figures of the novel coronavirus every 14 days across continents of the world. It indicates that the worst hit zones of the world are: Latin America and the Caribbean. On face value, one is likely to infer that the virus leapfrogs across regions of the world; however, taking the casualty quality of healthcare systems into account, it becomes easy to comprehend why Latin America and Caribbean are worst hit. Also, evidence suggests that data on the African continent does not present the reality of the Covid-19 pandemic as the continent lacks testing kits and facilities. Thus, while the casualty figure in the continent remains relatively low compared to other continents, the curve takes on a steady upward slope. It is informative to point out that majority of countries in both Africa and Latin America are developing countries whose capacity to profit from the global exchange is essentially limited due to their low productive capacity. The capacity of states is therefore a determinant of their ability to carry out surveillance, monitoring, containment, control and adaptation to pandemics in an increasingly globalized world.

\section{Conclusion}

Globalization has created numerous points of connection and exchange in the contemporary world, yet there remains a wide gap in disease surveillance and treatment capabilities of countries. This gap poses a serious issue of concern to the contemporary world following the ease in which pandemics spread across the globe. Owing to this gap, there is at least 2 decade gap in life expectancy between developed and developing countries (Sachs, 2015). While these differences cannot be attributed to a single factor, it is expected that the global exchange occasioned by globalization would make it easy for gains made in one part of the world to be deployed for the benefit of people living in other parts of the world. As can be seen from the analysis in this paper, this expectation has not been a reality. While globalization has eased the spread of pandemics to different parts of the globe, there has remained an uneven disease surveillance, containment and control capacity. This is largely due to the level of sophistication of their productive forces relating to disease management and control. Increased globalization has provided unprecedented level of interaction and movement amongst countries but the ability of countries to profit from this global exchange is dependent on the level of sophistication of their productive forces. The general capacity of states to produce and reproduce their healthcare needs is therefore crucial for their adaptation to changes posed by pandemics in an increasingly globalized world. Therefore, it is recommended that states should have their productive forces developed as the best way to ease the adaptation challenges posed by pandemics in a globalized world. 


\section{References}

Angalapu, D., \& Ikporukpo, I. (2020). Globalization and Development Debate in Africa: Changing the Conversation. ICRAW International Journal of Education and Social Research, 8(1), 82-94.

Avert. (2020). Origin of HIV \& AIDS The link between HIV and SIV When and where did HIV start in humans? Did HIV start in Africa? Global Statistics on HIV/AIDS1. https://www.avert.org/professionals/history-hivaids/origin

Atlas Magazine. (2020). Coronavirus in the top 10 worst epidemics in the last 50 years. Retrieved June 24, 2020, from Atlas Magazine: https://www.atlas-mag.net/en/article/coronavirus-in-the-top-10-worst-epidemics-inthe-last-50-years

BBC News. (2020). Coronavirus pandemic: Tracking the global outbreak. BBC News. https://www.bbc.com/news/world-51235105

European Center for Disease Prevention and Control. (2020). Coronavirus. ECDC. https://www.ecdc.europa.eu/en/coronavirus

Gallagher, J. (2014). Aids: Origin of Pandemic “was 1920s Kinshasa.” BBC News. https://www.bbc.com/news/health-29442642

Giovanni, J. Di, Gottselig, G., Jaumotte, F., Ricci, L. A., \& Tokarick, S. (2008). Globalization: An Overview. International Monetary Fund Policy Brief. https://www.imf.org/external/np/exr/ib/2008/053008.htm

Hahn, B. H., \& Sharp, P. M. (2011). Origin of HIV and AIDS pandemic. Cold Spring Harbor Perspective in Med, $1(1), 1-22$.

Homer-Dixon, T. F. (2000). Scarcity and conflict. Forum for Applied Research and Public Policy, 15(1), $28-35$. https://doi.org/10.2139/ssrn.229567

Ibrahim, A. A. (2013). The impact of globalization on Africa. International Journal of Humanities and Social Science's, 1(15), 85-93

International Organization for Migration. (2019). World Migration Report 2020. https://doi.org/10.1017/CBO9781107415324.004

Jones, T. C. (2012). America, Oil, and War in the Middle East. Journal of American History, 99(1), $208-218$. https://doi.org/10.1093/jahist/jas045

Knobler, S., Mahmoud, A., Lemon, S., \& Pray, L. (Eds.). (2006). The Impact of Globalization on Infectious Disease Emergence and Control: Exploring the Consequences and Opportunities. https://doi.org/10.1142/S0219622008003150

Kurt, D. (2020). The Special Economic Impacts of Pandemics. Investopedia. https://www.investopedia.com/special-economic-impact-of-pandemics-4800597

Little, B. (2020a). As the 1918 Flu Emerged, Cover-Up and Denial Helped It Spread - HISTORY. https://www.history.com/news/1918-pandemic-spanish-flu-censorship

Little, B. (2020b). How the 1957 Flu Pandemic Was Stopped Early in Its Path. History. https://www.history.com/news/1957-flu-pandemic-vaccine-hilleman

Ogban-Iyam, O. (2005). Social production and reproduction, societal conflicts and challenge of Democracy in Nigeria, University of Nigeria Journal of Political Economy, 1(1), 1-51

Ogban-Iyam, O. (2018). Nigeria: The Challenges and prospects of national unity Revisited. A Paper Delivered at the Faculty of Social Sciences Seminar Series, Niger Delta University.

Owen, J. (2020). 20 of the Worst Epidemics and Pandemics in History. Live Science. https://www.livescience.com/worst-epidemics-and-pandemics-in-history.html

Qiu, W., Rutherford, S., Mao, A., \& Chu, C. (2017). The Pandemic and its Impacts. Health, Culture and Society, 9, 1-11. https://doi.org/10.5195/hcs.2017.221

Roos, D. (2020). How 5 of History's Worst Pandemics Finally Ended. History. https://www.history.com/news/pandemics-end-plague-cholera-black-death-smallpox

Ruiz Estrada, M. A., \& Khan, A. (2020). Globalization and Pandemics: The Case of COVID-19. SSRN Electronic Journal, March, 10-19. https://doi.org/10.2139/ssrn.3560681

Sachs, J. D. (2015). The Age of Sustainable Development. Columbia University Press.

Saker, L., Kelley, L., Cannito, B., Gilmore, A., \& Campbell-Lendrum, Di. (2018). Globalization and infectious diseases: A review of linkages. In UNICEF/UNDP/World Bank/WHO Special Programme for Research \& Training in Tropical Diseases (TDR) (Issue 3). https://doi.org/10.1016/B978-1-78548-277-9.50008-5

Tuttle, M. L., \& Breit, B. G. (1999). Environmental Issues Associated with Fossil Fuel Resources - An Evaluation of Research Opportunities for the U.S. Geological Survey's Energy Resources Program. https://pubs.usgs.gov/of/1999/0590/report.pdf

Verikios, G., Sullivan, M., Stojanovski, P., Giesecke, J., \& Woo, G. (2015). Assessing Regional Risks From Pandemic Influenza: A Scenario Analysis. The World Economy.

Wells, G. J. (2001). The Issue of Globalization-An Overview. Congressional Research Service. http://digitalcommons.ilr.cornell.edu/crs/6\%0AThis 
WHO. (2005). Pandemic influenza preparedness and response: a WHO guidance document. In Global Influenza Programme (Vol. 369). https://doi.org/10.1017/CBO9781107415324.004

Williamson, J. (2018). Globalization: The Concept, Causes and Consequences. Peterson Institute for International Economics. https://www.piie.com/commentary/speeches-papers/globalization-concept-causes-andconsequences

Wu, J., \& Chow, D. (2020). Coronavirus diseases: Comparing COVID-19, SARS and MERS by the numbers. NBC News. https://www.nbcnews.com/health/health-news/coronavirus-diseases-comparing-covid-19-sars-mersnumbers-n1150321 